\title{
Phytochemical, Proximate, Vitamins, Minerals and Heavy Metals Composition of Two Indigenous Mushrooms (Daedaleopsis Confragosa, (Polyporaceae) and Russule Girolle (Cantharellus Cibarius)
}

\author{
Okwulehie, I. C. Okorie, D. O. And Egekonye, T. A. \\ Department of Biological Sciences, Michael Okpara University of Agriculture, Umudike, \\ P.M.B. 7267, Umuahia, Abia State, Nigeria.
}

\begin{abstract}
The phytochemical, proximate, vitamins, minerals, heavy metals and antimicrobial composition of two indigenous species of mushrooms namely Russule girolle (Rg) or Cantharellus, cibarius and Daedaleopsis confragosa $(D c)$ were investigated. The phytochemical constitute of the Mushrooms are as follows tannin, $1.88 \pm 0.02 \%$ for $R g$ and $2.74 \pm 0.100 \%$ for Dc), phenol $(0.41 \pm 0.02 \%$ for Rg and $-0.45 \pm 0.00 \%$ for Dc), sterol $(0.18 \pm 0.00 \%$, for $R g$ 0.23 $\pm 0.02 \%$ for Dc, HCN, $0.10 \pm 0.01 \%$ for $R g$ and $0.13 \pm 0.00 \%$ for Dc, saponin $0.84 \pm 0.0 \%$ and $20.78 \pm 0.02 \%$ ), alkaloid, $0.59 \pm 0.01 \%$ and $063 \pm 0.00 \%$, flavonoid, $3.32 \pm 0.08 \%$ and $2.96 \pm 0.00 \%$. for $R g$ and Dc respectively. Similarly the proximate composition in percentaces for Russule girolle(Rg) or Cantharellus, cibarius and Daedaleopsis confragosa were moisture, $(8.42 \pm 0.03$ and 8.79 \pm 0.07$)$, Ash $(8.53 \pm 0.08$ and

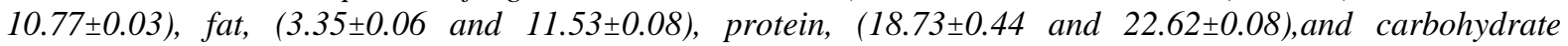
$(55.75 \pm 0.62$ and $41.12 \pm 0.27 \%)$ respectively. The result for vitamins were, B1, $(0.16 \pm 0.00$ and $0.19 \pm 0.0$ $\mathrm{mg} / 100 \mathrm{~g} 1), B 2,(0.45 \pm 0,00) \mathrm{mg} / 100 \mathrm{~g} B 3(1.37 \pm 0.02$ and $1.50 \pm 0.02 \mathrm{mg} / 100 \mathrm{~g})$, Vit $E,(0.31 \pm 0.02$ and $6.27 \pm 0.03$ $\mathrm{mg} / 100 \mathrm{~g})$ vit $A(1.85 \pm 0.01$ and $1.85 \pm 0.01 \mathrm{mg} / 100 \mathrm{~g})$ and $\mathrm{Vit} E(1.95 \pm 0.01$ and $1.96 \pm 0.00 \%)$ respectively, Mineral contents were calcium $(0.51 \pm 0.02 \mathrm{mg} / 100 \mathrm{~g}$ for $\mathrm{Rg}$ and $0.570 .03 \mathrm{mg} / 100 \mathrm{~g}$ for Dc. magnesium, $(0.18 \pm 0.00 \mathrm{mg} / 100 \mathrm{~g}$ for $\mathrm{Rg}$ and $0.23 \pm 0.00 \mathrm{mg} / 100 \mathrm{~g}$ for Dc, potassium $(1.94 \pm 0.02 \mathrm{mg} / 100 \mathrm{~g}$ for $\mathrm{Rg}$ and $0.2 .78 \pm 0.00 \mathrm{mg} / 100 \mathrm{~g}$ for $\mathrm{Dc})$, phosphorus $(0-12 \pm 0.00 \mathrm{mg} / 100 \mathrm{~g}$ for $\mathrm{Rg}$ and $0.09 \pm 0.00 \mathrm{mg} / 100 \mathrm{~g}$ for Dc), iron $(0.24 \pm 0.02 \mathrm{mg} / 100 \mathrm{~g}$ for $\mathrm{Rg}$ and $0.19 \pm 0.01 \mathrm{mg} / 100 \mathrm{~g}$ for $\mathrm{Dc})$. The heavy metals concentration of the mushrooms were, Lead (not detected), Copper $(0.03 \pm 0.000$ and 07 $\pm 0.00 \mathrm{ppm}$, cadmium, not detected, Mercury (not detected) zinc, $(0.12 \pm 0.00$ and $0.17 \pm 0.0)$ pmm respectively. The result obtained indicates that the mushrooms are of good quality. They are therefore recommended for maintenance of good health. They can also be exploited in the manufacture of drugs. Heavy metal levels obtained indicate that the mushrooms are safe for consumption but when consumed in very high quantity regularly may accumulate to toxic levels.
\end{abstract}

\section{Introduction}

Mushrooms are macro-fungi with distinctive body, which can be hypogenous or epigenous, and large enough to be seen with the naked eye and to pick by hand. (Okwulehie and Odunze, (2004b) Mushrooms have been appreciated as sources of food nutrients and pharmacologically important compounds useful in medicine. Mushrooms have long been used as a valuable food source and as traditional medicines around the world, especially in Japan and China, and recently other parts of the world. Records of health-promoting properties such as antioxidant, antimicrobial, anticancer, lowering of cholesterol and immune stimulatory and modulatory effects of mushrooms have been reported for many species of mushrooms (Anderson 1992). Some mushrooms stored glycogen and animal polysaccharide, while others have been implicated in other biochemical activities. (Konuk, (2006), Okwulehie and Odunze, (2004b) and Okwulehie and Ogoke, 2013). The health-enhancing properties of mushroom have been attributed to the presence of the bioactive compounds in mushrooms. Some of these biologically active substances are glycolipids, compounds derived from shikimic acid, aromatic phenols, fatty acid derivatives polyacetylamine, polyketides nucleosides, sesterterpenes and many other substances of different origins (Lorenzen and Anke, 1998, Wasser et al; 1999). Most of these bioactive compounds derived from mushroom are known to function as biological response modifier (BRM). Biological response modifiers are substances that stimulate the body's response to infection and disease. Edible mushrooms are regarded as epicurean delicacy. (Rambelli and Menini, 1983) reported that mushrooms are appreciated for their good taste and nutritional value and are used in soups, as meat supplement, as seasoning as well as flavouring. In Nigeria, the rural dwellers consume mushrooms as delicacies in soups and as ingredients for seasoning or part of the local melon cake (a local snack called 'USU' in Ibo land). The sclerotia of Pluerotus tuber-regium is used as thickener, as well as in preparing melon cake ('USU'). Bano, (1993) reported that mushrooms are rich in protein contents, which is almost twice that of vegetables and four times that of oranges. They have also been shown to be rich in free amino acids, fiber, vitamins and minerals while having low fat and 
carbohydrate content (Rambelli and Menin 1983). Mushrooms are good sources of vitamins like riboflavin, biotin and thiamine.( Bano, 1993). Edible wild mushrooms can contain a spectrum of mineral macro- and micronutrients, nonessential trace elements, and problematic heavy metals (Gucia et al, (2011) Organisms require trace amounts of some heavy metals, including iron, cobalt, copper, manganese, chromium, and zinc. Excessive levels of these metals, however, can be detrimental to organisms. Other heavy metals such as cadmium and lead have no known beneficial effect on organisms (Ouzouni, et al., 2009). The ability of mushroom species to bio-accumulate the minerals from the growth medium into the fruiting body is well documented (Rajarathnan, et al., 1998, Kalac, 2010). Because of ecological and genetic and other unknown factors, the fruiting bodies of higher mushrooms often are relatively rich in mineral constituents (Schmitt, et al., 2005, Varo et al., 1980, Vetter,1990). Environmental factors, species of mushrooms, part of fruiting body, developmental stages and age of mycelium, biochemical composition, and interval between the fructifications affect the bio-accumulation of minerals in macro fungi (Garcia, 1998, Mustafa, et al., 2005).

The present paper is focused on the analysis of two edible species of mushrooms to investigate their phytochemical, mineral, proximate and heavy metals compositions to discuss the results generated in relation to the epicurean utilization of the mushrooms and their implication in drugs for the treatment of diseases. The results would also show the limits of toxic metals the mushrooms contain. This is done in the perspective that mushrooms do significantly contribute to the essential nutrients requirements in the human diet. In other words the data derived would serve as a useful basis to exploit the nutritional and medicinal values of the mushroom species, along with any warnings or caution for toxicity of heavy metals as contained in the two mushrooms.

\section{Materials And Methods}

Fleshy and fresh mushrooms used in the study were purchased from Orieobibi market, while some were obtained from bushes around Umunam and Immerienwe in Ngor Okpala L.G.A of Imo State. Some were purchased from Ndoro market in Amawom Oboro Ikwuano LGA Abia State in May 2013. The samples were carefully sun-dried until they become brittle. This is as opposed to oven dry at $400^{\circ} \mathrm{C}$ employed by Okwulehie and Odunze (2004b).

\section{Preparartion Of Samples For Analysis}

The samples were ground into uniform powder using Corona blender (Landers), Model Y. CIA. S.A. 0897. (Okwulehie and Ogoke, 2013). The prepared samples were preserved in specimen bottles at room temperature in the Laboratory of the Department of Plant Science and Biotechnology, Michael Okpara University of Agriculture, Umudike until required for the various chemical tests.

\section{Quantitative estimation of the Chemicals:}

Each value is the mean of three replicate determinations \pm standard deviation.

Akaloids: Five grams (5g) of the dry powdered sample was used to determine the alkaloids contents of the mushroom following the method of Harborne (1973). The alkaloid was expressed as percentage.

\% Alkaloids: weight of residue $\quad$ x 100

\section{Determination of Flavonoids:}

$$
\text { weight of sample } 1
$$

About $5 \mathrm{~g}$ of the dry powdered sample was used to determine of Flavonoids according (Boham and Kocipai, 1994). The sample was mixed with $100 \mathrm{mls}$ of $2 \mathrm{~m} \mathrm{HCl}$ at room temperature. The solution was boiled for $30 \mathrm{~min}$ with water bath, cool and filtered. $20 \mathrm{mls}$ of Ethyl Acetate was added to the filtrate and filtered again with a weighed filter paper. The filter paper was oven dry, cool and weighed

\% Flavonoids: weight of residue $\quad$ x 100

$$
\text { Weight of sample } 1
$$

\section{Determination Of Tannin}

The method of Okeke and Elekwa, (2003) was used for tannin determination using $5 \mathrm{~g}$ of the sample shaken with $50 \mathrm{mls}$ of $\mathrm{H}_{2} \mathrm{O}$ and and left to stand for $30 \mathrm{~min}$. The solution was filtered and $2 \mathrm{mls}$ of the filtrates was introduced into a test tube and $3 \mathrm{mls}$ of $0.1 \mathrm{M} \mathrm{Fecl}_{3}$ and $2 \mathrm{ml}$ of potassium faro cyanide were added. Addition of $46 \mathrm{mls}$ of water was done. It was filtered again and $1 \mathrm{ml}$ of the filtrate was used to read the absorbance at $710 \mathrm{~nm}$ within $10 \mathrm{~min}$

\section{Determination Of Saponins}

Saponins determination was carried out using (Harborne, 1973) method, Five (5) g of the sample was boiled with $100 \mathrm{mls}$ of $20 \%$ ethanol in a water bath for $1.30 \mathrm{~min}$ and filtered while still hot. The filtrate was collected and heated for $30 \mathrm{~min}$, in $40 \mathrm{mls}$ of ether then poured into a separating funnel, the lower part of the filtrate in the separating funnel was collect and $60 \mathrm{mls}$ of n-butanol was added and the upper layer/part was 
collect while the lower part was discarded, the filtrate was evaporated to dryness using steam Bath at $70^{\circ} \mathrm{C}$. in an oven cooled and weighed.

\section{Determination Of Phenolic Content}

The total phenol content was determined using (Harborne, 1973) method. The fat free $0.2 \mathrm{~g}$ sample was boiled for $15 \mathrm{mins}$ with $50 \mathrm{ml}$ of ether for the extraction of phenol. five $\mathrm{ml}$ of the extract was pipetted into a $50 \mathrm{ml}$ flask and $10 \mathrm{ml}$ of distilled water was added also $2 \mathrm{ml}$ of ammonium hydroxide solution and $5 \mathrm{ml}$ of concentrated amyl alcohol were added and made up to mark and left to react for $30 \mathrm{~min}$ for color development. The absorbance of the solution was read at $505 \mathrm{~nm}$ wave length using a spectrophotometer.

\section{Moisture content determination}

\section{Proximate Analysis}

Five grams $(5.0 \mathrm{~g})$ of the powdered dry samples was placed into clean dry glass Petri dishes of known weight. These were placed in an electric oven at $15^{\circ} \mathrm{C}$ at $15^{\circ} \mathrm{C}$ and allowed to dry for 6-8 hours (La Guardia et al., 2005; Konuk et al., 2006).

The oven dried sample were weighed and placed back in the oven to further dry for 1 hour. The weighing and drying was repeated until the weight became content.

The percentage moisture content was calculated as follows.

$\%$ moisture: weight of residue $\mathrm{x} 100$

Ash Content

$$
\text { weight of sample } 1
$$

$1 \mathrm{~g}$ of the dry sample was used this value was obtained by weighing the sample before and after burning it at $50^{\circ} \mathrm{C}$ overnight (Mattila et al., 2002).

\section{Crude fiber}

The total fiber content was determined by the Weende method (AOAC 1980) 5.0g of the sample was placed into a $250 \mathrm{ml}$ beaker and hydrolyzed by adding $20 \mathrm{ml}$ of $25 \%$ sulphuric acid and boiled under control for about 30min on a hot plate. The mixture was filtered through a piece of clean white cloth then rinsed with hot distilled water. The residue was again boiled, with $50 \mathrm{ml}$ of $2.5 \%$ sodium hydroxide $(\mathrm{NaOH})$ for $30 \mathrm{~min}$, then filtered and rinsed with distilled water. The residue was finally collected and transferred into a crucible, dried in the oven to a constant weight. The weight of the fiber was calculated and expressed as a percentage of crude fiber as following

Crude fiber: weight of fiber $\quad$ 100

\section{Protein content}

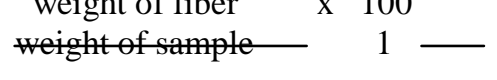

Protein content of the samples was determined by the use of the macro-kjeldahl method, protein contents were determined first and the value was multiplied by 6.25 coefficients (La Guardia et al., 2005). To determine the protein content, $1 \mathrm{~s} .0 \mathrm{~g}$ of the dry powdered sample was digested with $5 \mathrm{ml}$ of concentrated Tretraoxosulphate (vii) acid, to which a tablet of selenium catalyst was added in a fume cupboard. The digest was made up to mark in a $250 \mathrm{ml}$. volumetric flask. Ten $\mathrm{ml}$ of the digest was distilled and titrated with $0.2 \mathrm{~N}_{2} \mathrm{SO}_{4}$. The crude protein is therefore equaled to the $\mathrm{N}$ multiplied by a conversion factor, 6.25 .

\section{Determination Of Fats And Oil}

The fats and oil contents of the sample were determined following the Twisselman method using a diethyl-ether as solvent (AOAC, 1980). Five grams (5.0g) of the dry mushroom sample was introduced into an ether-extracting thimble and placed on a soxhlet reflux flask connected to a round bottomed flask of known weight. This was placed on a heating marital filled with about $250 \mathrm{ml}$ of petroleum ether. The oil was extracted by a reflux system. After a series of refluxes, a clear solution was obtained in the flask, the sample was removing. Further heating separated the ether from the extraction oil. The round-bottomed flask containing the oil was finally dried in an oven of $70^{\circ} \mathrm{c}$ determination by gravimetric method was done and expressed as a percentage of the sample used, thus.

$\%$ Fat and oil $=$ weight of fiber $\quad$ x 100

$$
1
$$

\section{Heavy Metals Determination}

The levels of copper lead, cadmium and zinc were determined using nitrogen, phosphorous and multielemental digestion method as described by Nivozamsky, et al., (1983). 


\section{Determination Of Minerals}

The levels of the mineral elements of calcium, magnesium, phosphorus, sodium, potassium and nitrogen were determined using the wet digestion extraction methods as describe by Nivozamsky et al., (1983).

\section{Vitamins Determination}

The determination of vitamins was carried out by the spectrophotometric method ( AOAC, 1980. The powdered samples were extracted by EDTA/TCA extraction method and the extracts read off at different wavelengths using the spectrophotometer.

Table 1a: Phytochemical composition of the two indigenous mushroom (\%)

\begin{tabular}{lll}
\hline Phytochemicals & Daedaleopsis confragosa(Dc) & Russule girolle $(\mathrm{Rg})$ \\
\hline Tannin & & \\
Phenol & $1.88 \pm 0.02$ & $2.74 \pm 0.00$ \\
Sterol & $0.41 \pm 0.02$ & $0.45 \pm 0.00$ \\
HCN & $0.18 \pm 0.00$ & $0.23 \pm 0.02$ \\
Saponin & $0.10 \pm 0.01$ & $0.13 \pm 0.00$ \\
Alkaloid & $0.84 \pm 0.02$ & $0.78 \pm 0.002$ \\
Flavonoid & $0.59 \pm 0.01$ & $0.63 \pm 0.00$ \\
\end{tabular}

Values are mean of three replicates \pm sd.

The result of the phytochemical composition of the mushrooms is presented in Table 1. The result shows that all the mushrooms contains alkaloids, flavonoids, phenols, saponnis, tannin, sterol, and hydrogen cyanide in varying quantities. However Dc contained the highest percentage of Flavonoids $(3.32 \pm 0.08 \%)$ and Saponin $(0.84 \pm 0.02 \%)$ while Rg had more tannin $(2.74 \pm 0.00 \%)$, alkaloid $(0.63 \pm 0.00 \%)$, and steroid $(0.23 \pm 0.02 \%)$. The HCN obtained in from both Dc and RG are quite low, $0.10 \pm 0.01$, and $0.13 \pm 0.00 \%$ respectively.

Table 2: Proximate composition of the two indigenous mushrooms (\%)

\begin{tabular}{lll}
\hline $\begin{array}{l}\text { Proximate } \\
\text { Parameters }\end{array}$ & Dc & $\mathrm{Rg}$ \\
\hline & & \\
Moisture & $8.42 \pm 0.03$ & $8.79 \pm 0.07$ \\
Ash & $8.53 \pm 0.08$ & $10.77 \pm 0.03$ \\
Fibre & $4.29 \pm 0.01$ & $5.18 \pm 0.02$ \\
Fat & $3.35 \pm 0.06$ & $11.53 \pm 0.08$ \\
Protein & $18.73 \pm 0.44$ & $2.62 \pm 0.08$ \\
Carbohydrate & $55.75 \pm 0.62$ & $41.12 \pm 0.27$ \\
\hline & & \\
Values are means of three replicates \pm sd. & & \\
\hline
\end{tabular}

Similarly, the result of proximate composition of the mushrooms is summarized in Table 2. The Protein content of Dc is significantly higher than that of $\mathrm{Rg}$ while the reverse is the case with fat content, $(3.35 \pm 0.06$ for Dc and $11.53 \pm 0.08 \%$ respectively). Carbohydrate content of the two mushrooms species were quite high $55.73 \pm 0.62$ for Dc and $41.12 \pm 0.27 \%$ respectively. Moisture and fibre contents the mushrooms (moisture, $8.42 \pm 0.03$ for DC, $8.79 \pm 0.07 \%$ for Rg and fibre, $4.29 \pm 0.01$ for Dc and $5.18 \pm 0.02 \mathrm{Rg}$ did not differ significantly.

Table 3. Percentage vitamin composition of the two indigenous mushroom (mg/100g)

\begin{tabular}{lll} 
Vitamins & Dc & Rg \\
\hline & & \\
B1 & $0.16 \pm 0.00$ & $0.19 \pm 0.001$ \\
B2 & $0.45 \pm 0.00$ & $0.45 \pm 0.00$ \\
B3 & $1.3 \pm 0.02$ & $1.50 \pm 0.02$ \\
C & $031 \pm 0.02$ & $0.27 \pm 0.03$ \\
A & $1.85 \pm 0.01$ & $1.85 \pm 0.001$ \\
E & $1.95 \pm 0.01$ & $1.96 \pm 0.00$ \\
\hline Values are means of three replicates \pm sd. & &
\end{tabular}

The results of the of the vitamin content investigation as presented in Table 3, shows that the two mushroom species are rich in vitamins B1, B2, B3, C, A and E. A closer look at the table 3 also shows that the quantity of each vitamin from the two mushroom species, do not differ considerably. 
Table 4. Mineral composition of the two indigenous mushrooms (mg/100g)

\begin{tabular}{lll}
\hline Mineral & Dc & $\mathrm{Rg}$ \\
\hline $\mathrm{Ca}$ & $0.51 \pm 0.02$ & $0.50 \pm 0.03$ \\
$\mathrm{Mg}$ & $0.18 \pm 0.00$ & $0.23 \pm 0.00$ \\
$\mathrm{~K}$ & $1.94 \pm 0.02$ & $2.78 \pm 0.00$ \\
$\mathrm{Na}$ & $0.41 \pm 0.09$ & $0.47 \pm 0.02$ \\
$\mathrm{P}$ & & $0.09 \pm 0.00$ \\
$\mathrm{Fe}$ & $0.12 \pm 0.00$ & $0.19 \pm 001$ \\
\hline Values are mean of three replicates \pm sd. & $0.24 \pm 0.01$ &
\end{tabular}

The result of the mineral composition of the mushrooms is summarized in table 4. Daedaleopsis confragosa(Dc) and Russule (Russula) girolle contain very high Potassiumin relation to the other minerals. Potassium content of R. girolle $(2.78 \pm 0.00 \mathrm{mg} / 100 \mathrm{~g})$ is however higher than that of $\mathrm{D}$. confragosa $(1.94 \pm 0.02$ $\mathrm{mg} / 100 \mathrm{~g})$. The the other minerals occurred in the following manner calcium $(0.51 \pm 0.02 \mathrm{mg} / 100 \mathrm{~g}$ for Rg and $0.570 .03 \mathrm{mg} / 100 \mathrm{~g}$ for Dc. ,magnesium, $(0.18 \pm 0.00 \mathrm{mg} / 100 \mathrm{~g}$ for $\mathrm{Rg}$ and $0.23 \pm 0.00 \mathrm{mg} / 100 \mathrm{~g}$ for Dc, phosphorus $(0-12 \pm 0.00 \mathrm{mg} / 100 \mathrm{~g}$ for $\mathrm{Rg}$ and $0.09 \pm 0.00 \mathrm{mg} / 100 \mathrm{~g}$ for $\mathrm{Dc})$, iron $(0.24 \pm 0.02 \mathrm{mg} / 100 \mathrm{~g}$ for $\mathrm{Rg}$ and $0.19 \pm 0.01$ $\mathrm{mg} / 100 \mathrm{~g}$ for Dc). calcium content obtained from Russule girolle with the highest of $(0.57 \pm 0.03)$ and lower of $0.51 \pm 0.00 \mathrm{mg} / 100 \mathrm{~g}$ with the least of $0.18 \pm 0.00$. Potassium content of the mushroom yielded the least of $(1.94 \pm 0.02 \mathrm{mg} / 100 \mathrm{~g})$ obtained from DC while RG yielded has the highest of $2.78 \pm 0.00$ obtained from DC while RG yielded has the highest of $2.78 \pm 0.00$. Sodium content yielded the highest $0.47 \pm 0.02 \mathrm{mg} / 100$ obtained from $\mathrm{RG}$ an yield the least $0.41 \pm 0.01$ obtained from DC.

Table 5.Heahy Metal composition of the two indigenous mushrooms (ppm)

\begin{tabular}{lll}
\hline Heavy Metals & $\mathrm{Dc}$ & $\mathrm{Rg}$ \\
\hline Lead & $\mathrm{Nd}$ & $\mathrm{Nd}$ \\
Cadmium & $\mathrm{Nd}$ & $\mathrm{Nd}$ \\
Copper & $0.03 \pm 0.00$ & $0.07 \pm 0.00$ \\
Argon & $\mathrm{Nd}$ & $0.02 \pm 000$ \\
Mercury & $\mathrm{Nd}$ & $\mathrm{Nd}$ \\
Zinc & $0.12 \pm 000$ & $0.17 \pm 000$ \\
\hline
\end{tabular}

Values are mean of three replicates \pm sd.

*Note Nd: not detected

The result of the heavy metal concentration of the mushrooms is summarized in table 5. The result shows that the two mushroom species do not contain lead and mercury. Argon was not also detected in D. confragosa while Copper and Zinc contained in Dc, $(0.03 \pm 0.00$ and0.12 $\pm 000 \mathrm{ppm}$ respectively) were nonsignificantly lower than those contained in $\mathrm{Rg},(0.07 \pm 0.00$ and $0.17 \pm 0.00 \mathrm{ppm}$ respectively).

\section{Discussion}

The results of the photochemical contents indicate that the two mushrooms contain Alkaloids, Tannins, saponins and phenols in varying quantities. These chemicals are considered to be antinutients because they have been reported to cause deleterious effects when consumed in large quantities. Some of them however, have been shown to have useful application in diets and certain biochemical activities in animals. Edeoga and Erita, (2001) observed powerful effect of alkaloids in animal physiology and showed their considerable pharmacological activities. Alkaloids and their synthetic derivatives are used as basic medicinal agents for analgesic antispasmodic and antibacterial effects (Stary, 1998). Similarly, phenols form the main constituents of most antiseptics and disinfectants. Thus the presence of phenolic compounds in the mushrooms species may be the reason for their antifungal, antiseptic and therapeutic properties, (Gill, 1992). The high Flavonoids of the mushrooms indicate that they have medicinal and antioxidants values. This is inferred from the report of Okwu, 2004 that flavonoids have medicinal values and antioxidants properties against free radical scavengers which prevent oxidative cell damage and have strong anticancer activity. The moderately high content of saponin in the mushrooms confirms their potential usefulness in medicinal and pharmaceutical industry due to its foaming ability that produces frothy effect in the food industry. Similarly tannin concentration of the mushrooms lays credence to the medicinal properties of the two mushrooms, since tannins possess astringent properties, which hasten the healing of wounds and inflamed mucous membrane (Okwu, 2004). The result also shows that the two mushrooms are good sources of protein and carbohydrate which are of great demand in both man and animals, confirming the report of Bano, (1993. However, the fact that Dc contains more protein $(18.73 \pm 0.022)$ than $\mathrm{Rg}$ $(2.62 \pm 0.08)$ places a premium on Dc over $\mathrm{Rg}$ as a protein source. The vitamin contents of the mushrooms are quite high (Table 3), and is in line with the report of Bano, 1993, that mushrooms are sources of riboflavin, 
biotin and thiamine. The mushrooms contain calcium, potassium, magnesium, phosphorus and sodium, the element are very important in human nutrition. This again supports the report of (Schmitt, et al., 2005, Varo et al., 1980, Vetter,1990 and Gucia et al, 2011). They are known to be involved in the repair of worn-out cells, strong bone and teeth, building blood cells and maintaining osmotic balance (WHO, 1996). The result in Table 5 indicates relatively low concentration of heavy metals in the mushrooms. Cadmium which is a highly toxic element is not detected in both mushrooms. According to Geng et al., 2005, the presence cadmium at elevated levels in soil and drinking water is reported to threaten food safety and human health. In humans too It affects biological activities and has detrimental effect on digestive, respiratory and immune system ( Geng et al., 2005). The moderately high concentration of zinc in the two mushrooms strengthens the opinion that they be recommended edibility and wide used throughout the world in medicines, foods, preventing corrosion in industries. According to Okwulehie and Ogoke, 2013, zinc is one of the most important mineral our body needs. This is because zinc is highly associated with protein and carbohydrate foods. Zinc is also used in medicines that treat rashes, acne, dandruff, athlete's foot. Similar to Cadmium in toxicity is Lead. Lead is known to be harmful in nature, serves as lead compounds in drug discovery and paints. Lead can cause kidney damage, miscarriages, anemia and rise in blood pressure. Copper is a trace element that is essential for human health. Cadmium and lead are known as principal toxic elements since they inhibit many vital processes. They can be taken up directly from water and, to some extent, from air and dietary food. These elements also have a tendency to accumulate in both plants and animals (Demirbas, 2001). Since the two heavy metals were not detected in the $\mathrm{Cd}$ and $\mathrm{Rg}$, this further makes them acceptable according to FAO/WHO, (1976) standards for $\mathrm{Cd}$ and $\mathrm{Pb}$ levels. According to FAO/WHO (1989), standards, acceptable intakes of $\mathrm{Cd}$ and $\mathrm{Pb}$ for an adult are 0.42-0.49 and 1.5-1.75 mg/week, respectively. The trace element concentrations in mushrooms are generally species-dependent (Kalac and Svoboda, 2000) and are hardly affected by the $\mathrm{pH}$ or organic matter content of the soil. Generally speaking the two mushrooms Daedaleopsis confragosa (Dc) and Russule girolle (Rg), are safe to be consumed based on their nutrients, safety and medicinal potentialities. More research work is however suggested in the area of characterization of the actual type of bioactive chemicals, (alkaloids, flavonoids, phenols, saponnis, tannin) they have.

\section{References}

[1]. Anderson J.B, and Stasovski E.(1992), Molecular phylogeny of Northern Hemisphere Species of Armillaria. Mycologia, 84: 505516 .

[2]. Association of Official Analytical Chemist (AOAC). (1980). Official method of analysis (13 ${ }^{\text {th }}$ Ed.) Association of Official Analytical Chemist Washington D C

[3]. Bano, Z. (1993). Food value of mushrooms. Gram Prandyogiki, 3:22-225

[4]. Boham, A.B. and A. Ckoeipai, (1994) Flavonoids and conversed tannins from leaves of Hawallan Vaccinium vaticulatum and V. calycinium pacific Sci. 48: 458-463.

[5]. Dunham S.M, O’Dell T.E, and Molina R. (2003). "Analysis of nrDNA Sequences and microsatellite allele frequencies reveals a cyyptic chanterelle species cantharelle species cantharellus cascadensis sp. Nor. From the America pacific Northwest". Mycological Research 107 (10): 1163- 77.

[6]. Edeoga, H.O. and Eriata, D.O. (2001). Alkaloids, Tannins and saponins contents of some medical plants. J. Med. Aromatic Plant Sci., 23: 344-349.

[7]. García, M.A., Alonso, J., Fernández, M.I. and Melgar, M.J. (1998). "Lead content in edible wild mushrooms in Northwest Spain as indicator of environmental contamination," Archives of Environmental Contamination and Toxicology, 34(4): 330-335.

[8]. Gill, S. (1992). Ethnomedial Uses of Plants in Nigeria. University of Benin Press, Benin Nigeria, 276p.

[9]. Gucia, M., JarzynskaG., Rafal, E., Roszak, M. Kojta, A. K., Osiej, I. and Falandysz,J. (2011). Multivariate analysis of mineral constituents of edible Parasol Mushroom (Macrolepiota procera) and soils beneath fruiting bodies collected from Northern Poland. Environ. Sci. Pollut. Res. Int. 19 (2): 416-431.

[10]. Harborne, J. B. (1973). Phytochemical Methods Chapman and Hall Ltd. London, PP 11-113.

[11]. Hug, Chen R. Proceeding of $5^{\text {th }}$ international medicinal Mushroom conference, Nantong, China 2009. The present situation of the industry development and marketing strategies of edible fungi in China; pp.538-543

[12]. Kalač, P. (2010). "Trace element contents in European species of wild growing edible mushrooms: a review for the period 20002009," Food Chemistry, 122(1): 2-15,

[13]. Konuk, M., Afyom, A., Yagiz, D. (2006). chemical composition of naturally growing edible mushrooms. Palldsrani Journal of Botany 38 (3): 799-804.

[14]. La Guardia, M., Venture, G. and Venturalla F. (2005). Chemical composition and nutritional value of Pleruotus taxa growing on umbellferous. plants (Apiaceaes). Journal of Agricultural and Food Chemistry 53, 5997-6002.

[15]. Leung M.Y.K., fung K.P., Choy Y.M., (1997). The isolation and characterization of an immunomodulatory and anti-tumor polysaccharide preparation from flammulina velutipes. Immunopharmacology.; 35:255-263.9.(pubmed).

[16]. Lorenzen K., Anke T. (1998). Basidiomycets as a source for new bioactive natural products. Current Organic Chemistry.2:329-364.

[17]. Mattila. P. ; Salo-Vaananem. P.: Konko, K; Heiki, A. and Jalava T. (2002). Basic composition and amino acid contents of mushrooms cultivated in Finland. Journal of agriculture and food chemistry. 53, 6419-16422.

[18]. Mustafa, S., Sibal, S., Mustafa, T. and Durali, M. (2005). "Determination of trace metals in mushroom samples from Kayseri, Turkey," Food Chemistry, 92 (4): 649-652.

[19]. Nivozamsky, I., Houba, V.J.G., Van Eck, R., and Van Vark, W. (1983). A novel digestion technique for multi-element plant analysis. Communication in Soil Science and Plant Analysis 14,239-248. 
[20]. Okeke, C. U. and Elekwa, I. (2002). Phytochemical study of the extracts of Gongronema latifolium Benth. (Asclepiadacea), J. Health Visual Sci. 5: 47-55.

[21]. Okwu, D. E. (2004). Phytochemicals and Vitamin Content of Indigenous spices of South-Eastern Nigeria, J. Sustain Agric. And Environs. 6: 30-34.

[22]. Okwulehie, I. C. and Odunze, E. I. (2004b). Evaluation of the Mycochemial composition of some tropical edible mushrooms. Journal of Sustainable Agriculture and environment 6(2):163-170

[23]. Okwulehie, I. C. and Ogoke, J. A. (2013). Bioactive, nutritional and heavy metal constituents of some edible mushrooms found in Abia State of Nigeria. International Journal of Applied Microbiologe and Biotechnology Research. 1: 7-15.

[24]. Ouzouni, P. K., Petridis, D., Koller, W. D. and Riganakos, K. A. (2009). "Nutritional value and metal content of wild edible mushrooms collected from West Macedonia and Epirus, Greece," Food Chemistry, 115(4):1575-1580,

[25]. Person O. (1997). The chanterelle Book. Berkeley, California: Ten speed press. ISBW o -89815-947-4

[26]. Rajarathnam, S., Shashirekha, M. N. and Bano, Z.(1998). "Biodegradative and biosynthetic capacities of mushrooms: present and future strategies," Critical Reviews in Biotechnology, v 18 (2-3): 91-236,

[27]. Rambelli, A., Menin, U.G. (1983). Manual on Mushroom Cultivation, F.A.O. Italy, 165pp

[28]. Redhead S.A, Norvell L.L, and Danell E. (1997). "Cantharellus formosus and the pacific Goloen chanterelle harvest in western North America". Mycotaxon 65:285-322

[29]. Reshetnikov S.V., Wasser S.P., Tan K.K., Higher basidiomycetes as a source of antitumor and immunostimulating polysaccharides (Review) international journal of medicinal mushrooms. 2001;3:361-394.

[30]. Rochon caroline; Pare. David; Pelardy, Nellia; khasa, Duinase P. ; FORTIN, J. Andre (2011). "Ecology and productivity of cantharellus cibarius var. roseo.canus in two eastern canadian jack pine stand "botany 89(10):663-675.do, 10.1139(b11-058). Varo, O., Lahelma, M., Nuurtamo, E., Saari, and Koivistoinen, P. (1980). "Mineral element composition of finish foods, vii. potato, vegetables, fruits, berries, nuts and mushrooms," Acta Veterinaria Scandinavica, 22, 89-113,

[31]. Schmitt, J.A., Meisch, H. U. and Reinle, W. (1977). "Heavy metals in higher fungi, II, manganese and iron,” Zeitschrift fur

[32]. Stary, F. (1998).The National Guide to Medicinal Herbs and Plants. Tiger Books International, London, PP. 12-16.

[33]. Vetter J. (1994). Potassium content of edible wild mushroom species. Zeitschrift für Lebensmittel Untersuchung Forschung 198: 33-35,

[34]. Vetter, J. (1990). "Mineral element content of edible and poisonous macrofungi," Acta ali zagon civilne družbe, 19, 27-40,

[35]. Wasser S. P. and Weis, A. L. (1999).Therapeutic effects of substances occurring in higher Basidiomycetes mushrooms: a modern perspective. Critical Reviews in Immunology. 19: (1)65-96

[36]. WHO, (1996). World Health Organization Technical Series. Trace Elements in human nutrition and Health. World Health Organization, Geneva, pp' 199-205. 